\title{
FAUNA OR PROTECTED AREAS - 8 NON-VOLANT SMALL MAMMALS OF KASU BRAHMANANDA REDDY NATIONAL PARK, ANDHRA PRADESH
}

\author{
C. Srinivasulu ${ }^{1 *}$, Bhargavi Srinivasulu ${ }^{1}$, A. Rajesh ${ }^{2}$, C.A.N. Rao ${ }^{2}$ and V. Nagulu ${ }^{1}$ \\ ${ }^{1}$ Wildlife Biology Section, Department of Zoology, Osmania University, Hyderabad, Andhra Pradesh 500007, India \\ ${ }^{2}$ Freshwater Biology Station, Zoological Survey of India, Ashoknagar, Hyderabad, Andhra Pradesh 500020, India \\ * Corresponding author (Email: hyd2_masawa@sancharnet.in)
}

\begin{abstract}
Field surveys carried out between August to December 2002 and trapping efforts between 25 to 30 October 2002 indicated the presence of 11 species of non-volant small mammals in the Kasu Brahmananda Reddy National Park, Hyderabad.

KEY WORDS

Andhra Pradesh, Insectivora, Kasu Brahmananda Reddy National Park, Lagomorpha, Pholidota, Rodentia
\end{abstract}

Faunal inventorying is one of the important tasks for precise taxon-specific and area-specific conservation efforts. Its relevance increases manifold in the light of conspicuous dearth of information about the biodiversity profile of the existing protected area network within the country. Although Zoological Survey of India (ZSI) has been documenting biodiversity of protected areas (PAs) for two decades, there are many more areas that need to be studied independently to augment the existing knowledge of the varied biodiversity of our country. Towards this end, the Zoology Department of the Osmania University, Hyderabad, has been contributing by conducting faunal surveys in many PAs of Andhra Pradesh (Nagulu et al., 1998; Srinivasulu \& Nagulu, 2002). Very recently the ZSI through its local research station - the Freshwater Biology Station, Hyderabad has undertaken profiling the biodiversity of four PAs in Andhra Pradesh. Realizing the lack of knowledge of non-volant small mammal diversity, the present study was undertaken by us to assess the same in one of the newly established, yet ecologically significant PA of the State.

Virtually no scientific study on small mammalian diversity had been carried out in Kasu Brahmananda Reddy National Park since its declaration as a Protected Area in 1998. Through this paper we briefly review the status of non-volant small mammals in this National Park.

\section{STUdY AREA}

The Kasu Brahmananda Reddy National Park (KBRNP) is situated in one of the rapidly developing sectors of Hyderabad in Jubilee Hills and spans over an area of 142.50ha.

The primary vegetation of the Park is that of tropical dry deciduous type with over 600 plant species (Sankaran pers. comm.). Open forest and dense scrub dominates the area covering about $45 \%$ of the land, while grasslands and dense forest cover $20 \%$ and $12 \%$ respectively. For convenience, the National Park that was earlier used by the citizens of Hyderabad for morning walks and leisure, was demarcated into two well- defined zones, namely - the Conservation Zone (spanning 88.5ha) and the Visitors Zone (54.0ha) by the State Forest Department. Entry into the former zone is strictly regulated, while the latter zone is open for public on nominal charge. This land was earlier under the control of nizams of the erstwhile Hyderabad State. The National Park has a palace that is the property of the nizam and is guarded meticulously by a contingent of private security force. The Park also has numerous dwelling and non-dwelling units within its boundary that covers an area of $24,356.02 \mathrm{~m}^{2}$.

\section{Methods}

The study area has been categorized into three habitat types rocky scrub, plain scrub, and human habitations, based on the major habitat characteristics. Line transects were laid passing through all the habitat types and animal presence was noted both by direct and indirect methods.

Sampling procedure: Eight to ten standard Sherman live traps $(22.9 \times 7.6 \times 8.9 \mathrm{~cm})$ were placed in each habitat type at intervals of $10 \mathrm{~m}$. A total of 140 trap nights were spent in trapping efforts. The traps were placed on the ground close to a tree, log or any other appropriate runway. They were baited with dry coconut, cheese, or banana. The traps placed near human habitations were occasionally baited with dry fish too. Traps were placed for five consecutive nights from 25 October to 30 October 2002. All the animals trapped were identified, marked, their morphometric measurements taken, sexed, and released. Rodents were identified following Agrawal (2000). Some examples trapped were collected as voucher specimens that were either deposited at the Freshwater Biology Station, ZSI, Hyderabad (FBS/ZSI) or at the Natural History Museum, Department of Zoology, Osmania University, Hyderabad (NHM.OU).

\section{Results and Discussion}

A total of 11 species of non-volant small mammals were recorded from the KBRNP (Table 1). The rodents were more diverse than the other major groups. The status of each species encountered during the study is briefly reviewed.

\section{Order Insectivora: Family Soricidae}

\section{Suncus murinus (Linnaeus, 1768) - House Shrew}

This is the only commensal insectivore that has been recorded from KBRNP. One female specimen was trapped on the night of 29 October 2002 near Gate 1 in human habitation. Dorsum brownish-gray, venter paler. Tail concolor to body being thick 
Table 1. Non-volant small mammals of Kasu Brahmananda Reddy National Park, Hyderabad

\begin{tabular}{|c|c|c|}
\hline Species & Data quality & Remarks \\
\hline \multicolumn{3}{|l|}{ Insectivora } \\
\hline Suncus murinus & Direct sighting & $\begin{array}{l}\text { Voucher specimen collected } \\
\text { NHM.OU Collection }\end{array}$ \\
\hline \multicolumn{3}{|l|}{ Rodentia } \\
\hline Funambulus pennanti & Direct sighting & $\begin{array}{l}\text { Voucher specimen collected } \\
\text { NHM.OU Collection }\end{array}$ \\
\hline Rattus rattus & Direct sighting & $\begin{array}{l}\text { Voucher specimen collected } \\
\text { FBS/ZSI Collection }\end{array}$ \\
\hline Mus platythrix & Direct sighting & $\begin{array}{l}\text { Voucher specimen collected } \\
\text { FBS/ZSI Collection }\end{array}$ \\
\hline Mus musculus & Direct sighting & $\begin{array}{l}\text { Voucher specimen collected } \\
\text { FBS/ZSI Collection }\end{array}$ \\
\hline Millardia meltada & Direct sighting & $\begin{array}{l}\text { Voucher specimen collected } \\
\text { FBS/ZSI Collection }\end{array}$ \\
\hline Bandicota bengalensis & Direct sighting & $\begin{array}{l}\text { Voucher specimen collected } \\
\text { FBS/ZSI Collection }\end{array}$ \\
\hline Bandicota indica & Indirect evidence & $\begin{array}{l}\text { Forest Dept. Source } \\
\text { Direct sightings outside the } \\
\text { National Park by us }\end{array}$ \\
\hline Hystrix indica & $\begin{array}{l}\text { Indirect evidence } \\
\text { (Quills observed) }\end{array}$ & Forest Dept. Source \\
\hline \multicolumn{3}{|l|}{ Pholidota } \\
\hline Manis crassicaudata & Indirect evidence & Forest Dept. Source \\
\hline \multicolumn{3}{|l|}{ Lagomorpha } \\
\hline Lepus nigricollis & $\begin{array}{l}\text { Direct sighting } \\
\& \text { droppings }\end{array}$ & Not collected \\
\hline
\end{tabular}

Key: NHM.OU - Natural History Museum, Osmania University, Hyderabad; FBS/ZSI - Freshwater Biology Station, Zoological Survey of India, Hyderabad

at the base and narrow at the tip and is sparsely covered with long bristles.

\section{Order Rodentia: Family Sciuridae \\ Funambulus pennanti Wroughton, 1905 - Five-striped Palm Squirrel}

The five-striped palm squirrel is the only sciurid that has been recorded from the KBRNP. It was commonly found near human habitation and also in the plain scrub. A female specimen was trapped on 28 October near a well in the Conservation Zone. Dorsum dusky greenish-gray and bears five pale yellowishwhite stripes along the whole length of the back. Venter whitish. Tail fluffy with hairs streaked with red and black.

\section{Family Muridae \\ Rattus rattus (Linnaeus, 1758) - Common House Rat}

Common near human habitation. A male specimen was trapped near Gate 1 in human habitation on 26 October. Dorsum brownish, venter dirty white. Tail longer than the body and is concolor.

\section{Mus platythrix Bennett, 1832 - Brown Spiny Mouse}

One of the uncommon species of rodents in the KBRNP. One male individual was trapped on 25 October in the plain scrub habitat near the lake. Dorsum dark brown and venter greyishwhite. Tail shorter than the body and is bicolour. Hind feet characteristically white. It seems to like scrub habitats and has also been observed from many localities within the urban sprawl of Hyderabad and Secunderabad.
Mus musculus castaneus Waterhouse, 1843 - House Mouse The common house mouse seemed to be more commoner near human habitations than in other habitats of the Park. One nonperforated female was trapped on the night of 27 October near human habitation adjacent to Gate 1. Dorsum dark brownishwhite, venter in a lighter shade. Tail faintly bicoloured, pointed and sparsely haired. Toes of the hindfoot lighter but not white.

\section{Millardia meltada (Gray, 1837) - Soft-furred Metad}

Most abundant of the murids in the Park. A total of 13 individuals (including three young ones) were trapped on all trapping nights. A soft-furred rat with tail shorter than the head body length. Ears rounded and shorter than hindfoot. Plantar pads five. Females bear two pairs of teats. Dorsum greyish-brown while the venter greyish-white. Tail distinctly bicoloured. These were observed to have affinity to rocky areas, and all the specimens trapped in the plain scrub habitat were always in the vicinity of rocky boulders. Among the five females trapped two were perforated while the rest were nonperforated with one being gravid while another with a vaginal plug. Although it breeds throughout the year, the peak breeding season extends from the month of March to September (Mohan Rao, pers. comm.). A female specimen trapped on 27 October was collected. The morphometric measurements of the three female specimens trapped (but released) ranged between - HB: 79.2-144.5mm, T: 69.5-134.0mm, E: 14.1-21.0mm, HF: 24.5-27.1mm. Tail length of a male was $132.0 \mathrm{~mm}$, no other measurements could be taken. Young ones and other specimens were not measured.

\section{Bandicota bengalensis (Gray, 1835) - Indian Mole Rat}

The Indian Mole Rat was recorded only from the pump house near the large waterbody within the Park. It was observed coexisting along with the House Rat. A young male specimen was trapped in the pump house on 28 October. Dorsum blackish-brown, venter a shade lighter. Tail shorter than the body and is darkish.

\section{Bandicota indica Bechstein, 1800 - Large Bandicoot Rat}

This is reported to be common around human habitations, especially along the living quarters near the Gate 1 of the National Park. During the study, its faeces were found in two locations near a small garbage dump behind the living quarters of the forest staff. The Large Bandicoot Rat had been regularly observed near the shanties and vegetable shops in the vicinity of the National Park. One of the forest department staff living within the National Park reported sighting of an albino individual of this species for a brief period of about 14-18 days before 20 October, 2002. Our efforts to sight or trap the specimen proved futile.

\section{Family Hystricidae}

Hystrix indica Kerr, 1792 - Indian Crested Porcupine

This large-sized rodent with characteristically long brown quills with alternate white and black bands has been reported to be present in the National Park but was not sighted by us. We found indirect evidence, such as quills and scats, indicating its presence in the Park. 
Table 2. External measurements of non-volant small mammals collected during the study

\begin{tabular}{|c|c|c|c|c|c|c|}
\hline \multirow[t]{2}{*}{ Species } & \multirow{2}{*}{$\begin{array}{l}\text { No. of ex. } \\
\text { collected }\end{array}$} & \multirow[t]{2}{*}{ Voucher at } & \multirow[b]{2}{*}{ HB } & \multicolumn{3}{|c|}{ Measurements (in mm) } \\
\hline & & & & $\mathbf{T}$ & E & HF \\
\hline Suncus murinus & 1 & NHM.OU MAMM/INS 1/2001 & 107.5 & 57.6 & 10.5 & 19.1 \\
\hline Funambulus pennanti & 1 & NHM.OU MAMM/ROD 1/2002 & 165.1 & 147.2 & 16.1 & 37.1 \\
\hline Rattus rattus & 1 & FBS/ZSI/N/1134 & 108.0 & 158.0 & 19.0 & 27.5 \\
\hline Mus platythrix & 1 & FBS/ZSI/N/1137 & 74.6 & 59.2 & 12.0 & 14.2 \\
\hline Mus musculus & 1 & FBS/ZSI/N/1136 & 77.8 & 87.1 & 12.0 & 16.2 \\
\hline Millardia meltada & 1 & FBS/ZSI/N/1135 & 79.6 & 59.2 & 12.0 & 14.2 \\
\hline Bandicota bengalensis & 1 & FBS/ZSI/N/1139 & 133.0 & 118.0 & 18.3 & 32.3 \\
\hline
\end{tabular}

NHM.OU - Natural History Museum, Osmania University, Hyderabad; FBS/ZSI - Freshwater Biology Station, Zoological

Survey of India, Hyderabad; HB - head-body length; T - tail length; E - ear length; HF - Hindfoot length

\section{Order Pholidota: Family Manidae}

Manis crassicaudata Gray, 1827 - Indian Pangolin

Although this species has become rare in the vicinity of Hyderabad City, its presence in the KBRNP is a good sign. The Forest Department staff informed us about one specimen of Indian Pangolin recently caught within the National Park that was latter shifted to the Nehru Zoological Park, Hyderabad (Shekar, pers. comm.). We did not come across this species during the present study.

\section{Order Lagomorpha: Family Leporidae}

\section{Lepus nigricollis Cuvier, 1823 - Indian Hare}

The Indian (or Black-naped) Hare is ubiquitous and the only hare found in the Park. We sighted or recorded indirect evidence almost all throughout the study period. Our observations on the encounter frequency of the fresh droppings indicates that this species could not be as abundant as perceived and the numbers in the National Park is not building up due to predation by feral dog and Rock Python.

\section{REFERENCES}

Agrawal, V.C. (2000). Taxonomic studies on Indian Muridae and Hystricidae (Mammalia: Rodentia). Records of the Zoological Survey of India, Occassional Paper No. 180. 177pp+6pl.

Srinivasulu, C. and V. Nagulu (2002). Mammalian and avian diversity of the Nallamala Hills, Andhra Pradesh, India. Zoos'Print Journal 17(1): 675-684.

Nagulu, V., V.V. Rao and C. Srinivasulu (1998). Biodiversity of select habitats in Eastern Ghat regions of Andhra Pradesh. Proceedings of the Seminar on Conservation of Eastern Ghats. EPTRI, Hyderabad, pp.6-35.

\section{ACKNOWLeDGements}

We thank the Director, Zoological Survey of India, Kolkata; Sally Walker, Zoo Outreach Organisation, Coimbatore; and Head, Department of Zoology, Osmania University for facilities and encouragement. Special thanks are extended to Chief Wildlife Warden, Andhra Pradesh Forest Department, Hyderabad for collection permit and special interest in the biodiversity documentation work undertaken by us. We thank Mr. A. Shankaran ACF, Mr. L.R. Shekar FRO and other staff of the KBR National Park for providing us necessary help during the study. We also thank Dr. A.M.K. Mohan Rao of National Plant Protection and Training Institute, Hyderabad for helping in identifying rodents and sharing information. CS is grateful to RILSCINSA, Coimbatore for providing Sherman traps to conduct this study. CS and BS acknowledge respective fellowships from CSIR, New Delhi.

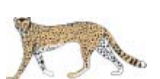

\begin{tabular}{|c|}
\hline 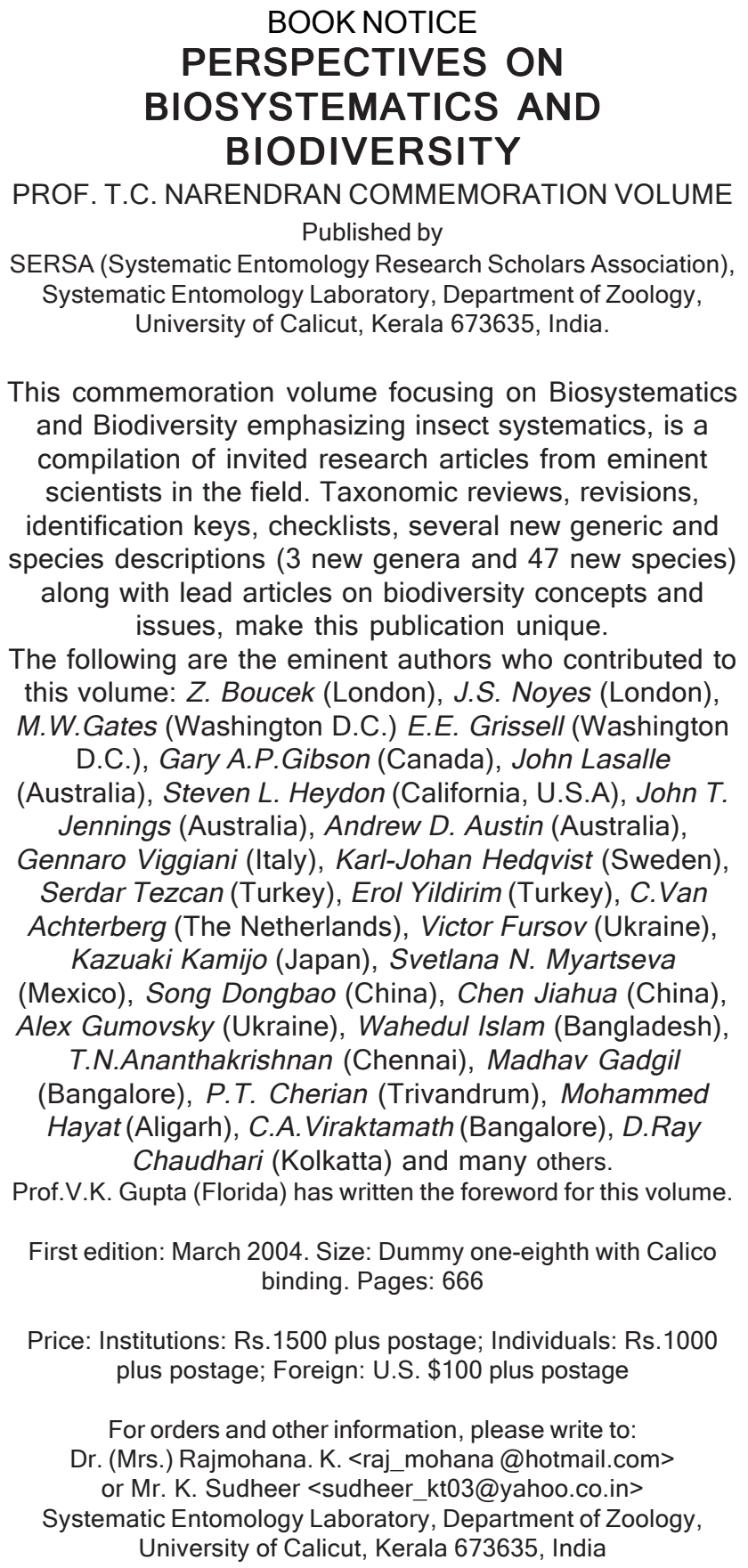 \\
\hline
\end{tabular}

